Finn Frandsen*

\title{
Tekst, sekvens og heterogenitet \\ Introduktion til J.-M. Adams teori om teksttyper
}

\begin{abstract}
The present paper gives a critical introduction to the theory of text types or text sequences elaborated by the French text linguist Jean-Michel Adam. The first part of the paper presents the overall theoretical framework for Adam's research within stylistics and text linguistics. The second part of the paper gives a more detailed discussion of Adam's answers to what may be defined as the four most crucial questions within text type research, that is: a) the number of text types which can be identified (the classification problem), b) the relation between text types within individual texts, c) the relation between text types and linguistic features and d) the relation between text types and their communicative function (the interaction between form and function).

L'objectif de la linguistique textuelle est simple : poursuivre l'analyse linguistique au-delà de la phrase complexe et des seuls couples de phrases et, si difficile que cela paraisse, accepter de se situer aux frontières du linguistique dans le but de rendre compte de l'hétérogénéité de toute composition textuelle.
\end{abstract}

J.-M. Adam: Les textes : types et prototypes (1992: 20)

\section{Indledning}

Teksttyper er både et centralt forskningsområde inden for moderne tekstlingvistik og et område, hvis historiske rødder går langt tilbage. Allerede $\mathrm{i}$ antikken indgik teksttyper således som element i retorikken, f.eks. i de såkaldte progymnasmata, de indledende stilskrivningsøvelser, som eleverne i retorik skulle gennemgå under ledelse af en grammatikós (Hastrup 1976: 99-100). Og fremstillingsformer som f.eks. den beskrivende, den fortællende eller den argumenterende tilhørte læren om dispositio, den anden af retorikkens fem partes (Fafner 1977: 18-

* Finn Frandsen

Fransk Institut

Handelshøjskolen $i$ Århus

Fuglesangs Allé 4

DK-2810 Århus $V$

Hermes, Journal of Linguistics no. 20 - 1998 
19). Fra renæssancen og helt frem til vort århundrede har teksttyper indgået som en fast bestanddel af lære- og håndbøger i retorik, stilistik og kompositionslære. ${ }^{1}$

Forskningen i teksttyper har stor relevans inden for mange områder. Som det fremgår af såvel ældre som nyere indføringer i tekstlingvistik (se f.eks. Beaugrande/Dressler 1981: 182-84 eller Heinemann/Viehweger 1991: 129-175), repræsenterer teksttyper for det første et vigtigt aspekt af en teksts struktur, og det ikke mindst takket være deres status som et organisationsplan, der befinder sig mellem på den ene side tekstens mikroplan og på den anden side tekstens makroplan (jf. Adam 1990: 96). For det andet er viden om teksttyper og de kognitive skemaer, som disse er forbundet med, af stor betydning for studiet af produktion og/eller reception af tekster (jf. Adam 1992: 7). Det gælder også den didaktiske dimension af dette studium, hvad enten der er tale om undervisning i modersmål eller fremmedsprog. ${ }^{2}$ Endelig har det også vist sig, at forskningen i teksttyper har kunnet finde anvendelse inden for andre lingvistiske eller nært beslægtede områder som f.eks. oversættelsesvidenskab (jf. Hatim/Mason 1990: 149-160).

Formålet med denne artikel er at give en kritisk introduktion til den franske tekstlingvist Jean-Michel Adams teori om teksttyper eller som han selv ville kalde det: hans teori om tekstsekvenser. At en introduktion til denne teori er nødvendig, skyldes ikke blot, at Adams bøger og artikler hidtil kun har været tilgængelige på fransk, men også, at hans teori har udviklet sig betragteligt fra midten af 80'erne og frem til i dag; ved at følge denne udvikling kan man kaste nyt lys over de almene problemer, som forskningen i teksttyper i dag står over for. At denne introduktion tillige må være kritisk beror på, at Adams teori, som det forhåbentlig vil fremgå af artiklen, langt fra er problemfri.

Artiklen falder i fem dele. Med udgangspunkt i Frandsen/Pilegaard (1997) vil jeg først opstille en oversigt over de problemstillinger, som

1 Se f.eks. Adam/Petitjean (1989: 7-78) og Adam (1993: 5-66), hvor man kan finde en historisk redegørelse for den status, som den beskrivende teksttype (eksphrasis, descriptio) har haft inden for retorik, stilistik og kompositionslære fra antikken og frem til i dag.

2 Faglitteraturen om brugen af teksttypologier i sprogundervisningen er efterhånden ganske omfattende. Jeg vil derfor nøjes med at henvise til de sidste femten års diskussion om "la diversification de l'enseignement du français écrit" i Frankrig og Schweiz (se f.eks. Bronckart 1991, Coste 1991 og Schneuwly 1991). 
må antages at være de mest centrale inden for forskningen i teksttyper (sektion 2). Dernæst vil jeg præsentere Adams tekstlingvistiske forskning som sådan samt give en introduktion til den teoretiske ramme, han arbejder inden for (sektion 3). Derefter følger en kritisk diskussion af de svar, Adam kan give på de netop omtalte problemstillinger (sektion 4). Det er først og fremmest på grundlag af denne diskussion, at Adams teori om teksttyper skal evalueres. Endelig vil jeg i afslutningen (sektion 5) kort diskutere den kritik, som er blevet rettet imod Adam, og i forlængelse heraf forsøge at skitsere de fremtidige perspektiver for denne gren af tekstlingvistikken.

\section{Centrale problemstillinger inden for forskning i tekst- typer}

Eftersom der inden for typologisering af tekster både eksisterer en vis begrebsforvirring og store terminologiske forskelle mellem de nationale forskningstraditioner, vil jeg begynde med at definere, hvad man skal forstå ved teksttype i denne sammenhæng (for en oversigt over området, se Frandsen 1995a samt Frandsen 1995b: 59-60).

Ved teksttype vil jeg ikke forstå tekstgenrer som f.eks. en kriminalroman, en lederartikel, en imagebrochure eller en teknisk manual, men derimod det, som undertiden også kaldes for fremstillingsformer. I et af sine værker om den fortællende teksttype udlægger Jean-Michel Adam forskellen mellem teksttype og tekstgenre som en forskel mellem noget, der er invariabelt, og noget, der er variabelt: "le récit n'est pas un genre littéraire (donc une variable culturelle), mais un type (invariant) d'organisation - donc de cohésion - des énoncés" (Adam 1985a/1994: 4).

Teksttyper defineres klassisk ud fra tre forskellige sæt af kriterier: 1) den kognitive operation, som teksttypen repræsenterer, f.eks. at beskrive, at fortælle, at forklare eller at argumentere; 2) de sproglige midler, der er forbundet med denne operation, f.eks. brugen af bestemte typer af verber eller konnektorer (strukturelt kriterium); 3) den kommunikative funktion, som afsender har intention om at realisere ved hjælp af den kognitive operation og de sproglige midler (funktionelt kriterium).

Frandsen/Pilegaard (1997) udpeger fire centrale problemstillinger, som enhver forskning i teksttyper må tage stilling til, og som kort vil blive præsenteret i det følgende. 


\subsection{Antallet af teksttyper}

Den første problemstilling vedrører spørgsmålet om, hvor mange teksttyper det er muligt at identificere. Ifølge den mest udbredte klassifikation (se f.eks. Werlich 1975 og 1976 eller Virtanen 1992) kan der skelnes mellem i alt fem forskellige typer, her illustreret med danske eksempler fra forskellige tekstgenrer: ${ }^{3}$

\section{Den beskrivende teksttype}

(1) Provence's kæmpe har mange navne

Mont Ventoux nordøst for Carpentras er bjerget, som næsten altid er synligt inden for 75-100 km afstand, da det med sine $1.909 \mathrm{~m}$ er Alpernes sidste store - og enestående - krampetrækning i vest.

Som et andet Fuji Yama - eller måske snarere som et forvokset muldvarpeskud - hæver det sig dominerende langt op over omgivelserne, og en dag på dette bjerg hører med til enhver Provence-tur.

Kært barn har mange navne. Mont Ventoux kommer af romernes latinske Mons Ventosus, "Det blæsende Bjerg", hvad der er et yderst rimeligt navn, idet toppen næsten altid er svøbt ind i blæst selv på klare dage. Når mistralen (mestervinden) kommer susende ned gennem den smalle Rhône-dal, er det her, den kan medtage kulde til sin videre færd.

Ventoux kaldes også "Det skaldede Bjerg", og Fuji Yama sammenligningen er slet ikke helt ved siden af, for det første stykke op mod toppen er altid helt hvidt. Fra december til april er det sne, man ser, men siden åbenbares en anden form for hvidt, en hvid kalkstensørken uden vegetation. Derfor er der hverken læ eller skygge på den $\emptyset$ verste del, når vinden blæser, og solen brænder, og så er der ellers stejlt med stigninger fra 6 til 14\%.

(Uddrag af turistguide Provence rundt)

\section{Den fortællende teksttype}

(2) Tyggegummiets historie

I hele menneskehedens historie har man tygget på noget. Svenske arkæologer har fundet et 10.000 år gammelt stykke tyggegummi med tandaftryk.

3 Det skal med det samme understreges, at ingen af disse eksempler på de "klassiske" teksttyper er homogene. Jeg skal vende tilbage til dette spørgsmål i afsnit 4.2. 
I Grækenland tyggede kvinderne gummiagtig harpiks mastiks. Eskimoerne har tygget på skind, Sydamerikas befolkning på rødder og forskellige blade. Stenalderfolket har tygget på ler og græs.

Det tyggegummi, vi kender i dag, blev opfundet i 1887 af en amerikaner ved navn Adams. Han lavede tyggegummi af chiclet, som er en gummitype, der stammer fra sapodillatræet i Sydamerika.

Tyggegummi blev kendt i Europa omkring århundredskiftet og kom til Danmark i 1909.

(Uddrag af Dandy virksomhedsportrat)

\section{Den fremstillende teksttype}

(3) Forskellen mellem den kristne og den islamiske gudsforståelse

De tre monoteistiske religioner, jødedommen, kristendommen og islam, har fælles udspring i Abrahams gamle bekendelse til den ene Gud, som alene er Herre. (Abraham, som på arabisk kaldes Ibrahim, betragtes som den første egentlige "hanif" (monoteist)). Midtpunktet for alle tre religioner er Jahve, Gud eller Allah. Tre forskellige betegnelser for den samme Gud.

Ordet "Allah", som kommer af det arabiske ord "ilah", betyder Gud og svarer til det hebraiske ord "eloah". De arabiske kristne i den arabiske verden kalder også deres Gud for Allah.

Men der er forskel på den kristne og den islamiske forståelse af Gudsbegrebet. Mens en muslim i hele sin menneskelige eksistens og erfaring er bundet til Gud, ser den kristne sin erfaring om Gud koncentreret i et menneske, nemlig Jesus. Guds virkelighed findes i Jesu liv, prædiken, lidelse, korsfæstelse og opstandelse. I kristendommen møder Gud mennesket på helt menneskelig måde.

Islams Gudsforståelse ligger tættere op ad jødedommens.

(Uddrag af N. Khader: Are og skam)

\section{Den argumenterende teksttype}

(4) Førstehjælp

Akut sygdom og ulykke kan ramme enhver, men det er ikke noget, vi til daglig bekymrer os alt for meget om. Vi tager det for givet, at hjælpen er nær, hvis uheldet er ude. 
Og vi forventer, at hjælpen kommer hurtigt og er kvalificeret. Ikke desto mindre har en række artikler her i avisen dokumenteret, at det står skralt til med hjælp fra 112.

Det kan umiddelbart lyde imponerende, at vi i lille Danmark er udstyret med ikke mindre end 41 alarmcentraler, men kvantiteten dækker over forældet teknologi og manglende overblik. Nu om dage sker stadig flere 112opkald fra en mobiltelefon. For at sikre, at disse samtaler ender på den rigtige alarmcentral, går alle mobilopkald $\mathrm{i}$ dag via en central omstilling hos Tele Danmark. Dette forsinkende mellemled minimerer risikoen for, at den forkerte alarmcentral sender en ambulance til den forkerte Møllegade i den forkerte by. Men det koster tid.

Hertil kommer, at telefonen på alarmcentralerne betjenes af politifolk uden sundhedsfaglig indsigt. De er ude af stand til at give råd om, hvordan en tilskadekommen kan hjælpes i de livsvigtige minutter, inden en ambulance når frem. Politiet lader besked og adresse på ulykkesstedet gå videre til redningsfolkene. Derpå afbrydes forbindelsen. Det koster liv.

Derfor må alarmsystemet laves om. Tre fjerdedele af alle opkald til 112 drejer sig om ambulancebistand. Derfor må det som i Sverige være sundhedsfagligt uddannet personale, der tager telefonen - og holder forbindelsen, så længe det er nødvendigt. Samtidig må antallet af centraler reduceres. CD foreslår i dagens avis fem alarmcentraler. Det lyder realistisk.

(Uddrag af lederartikel fra dagbladet Politiken)

\section{Den instruerende teksttype}

(5) Det Naturlige Skridt

Som eneste hotelkæde samarbejder Scandic med den højt anerkendte svenske miljøorganisation "Det Naturliga Steget". Organisationen blev grundlagt i Sverige i 1989 af kræftforskeren Karl-Henrik Robért. Den er uafhængig af politik og religion, og dens arbejde hviler på videnskabeligt grundlag.

"Det Naturliga Steget's" arbejde er baseret på fire systemvilkår. Forskere og videnskabsmænd er enige om, at enhver seriøs indsats for miljøet skal bygge på disse vilkår:

1. Hent ikke mere ud fra jordens indre, end der kan genskabes der. 
2. Benyt ikke unaturlige og ikke-nedbrydelige materialer, som f.eks. freon, PCB og DDT.

3. Bevar de naturlige grønne områder og naturens artsrigdom.

4. Udnyt jordens ressourcer effektivt og retfardigt.

(Uddrag af folder til hotelgæster fra Scandic Hotels

Vi må alle tage et medansvar for vort falles miljø)

Denne klassiske fem-delte klassifikation er som sagt den mest udbredte, men den er dog langt fra den eneste. Blandt andre Longacre (1982, 1983) og Biber $(1988,1989)$ opstiller alternative klassifikationer, der omfatter henholdsvis fire og otte mere eller mindre overlappende typer. ${ }^{4}$ At der kan være så store udsving i antallet af teksttyper, viser ikke alene, at der ofte arbejdes ud fra forskellige kriterier, men tillige, at der er tale om fænomener, som det kan være vanskeligt at klassificere entydigt.

\subsection{Relationen mellem teksttyper inden for samme tekst}

Den anden problemstilling vedrører relationen mellem teksttyper inden for samme tekst. Der skelnes således ofte mellem homogene tekster (eller det, som Virtanen (1992) kalder unitype texts), hvor kun én teksttype er repræsenteret, og heterogene tekster (multitype texts $\mathrm{i}$ Virtanens terminologi), hvor flere forskellige teksttyper er repræsenteret.

I det sidste tilfælde bliver det naturligvis nødvendigt at undersøge, hvilke former relationen mellem de forskellige teksttyper kan antage. I (2) er der tale om en heterogen tekst, hvor to forskellige teksttyper - en fremstillende og en fortællende - optræder sammen. Men hvordan skal man beskrive relationen imellem dem?

Den mest udbredte forklaringsmodel er dominansmodellen, der går tilbage til Morris (1946) og Jakobson (1960), og ifølge hvilken man kan

4 Longacre skelner imellem 1) narrative discourse, 2) procedural discourse, 3) behavioral discourse og 4) expository discourse. Biber skelner imellem: intimate interpersonal interaction, 2) informational interaction, 3) scientific exposition, 4) learned exposition, 5) imaginative narrative, 6) general narrative, 7) situated reportage og 8) involved persuasion. Som det tydeligt fremgår af Bibers klassifikation, ligger nogle af typerne meget tæt op af det, vi ovenfor har defineret som tekstgenrer (f.eks. scientific exposition), eller udgør underkategorier (f.eks. imaginative narrative/general narrative). 
udpege den teksttype, som dominerer over de andre, og som gør det muligt at hævde, at en tekst taget under ét kan analyseres som værende enten beskrivende, fortællende, fremstillende, argumenterende eller instruerende. (2) kan således analyseres som en tekst, hvor den fortællende teksttype er den dominerende, og hvor den fremstillende teksttype blot tjener som indledning.

\subsection{Relationen mellem teksttyper og de sproglige midler, hvormed disse realiseres}

Den tredje problemstilling vedrører spørgsmålet, om det er muligt at identificere en bestemt teksttype på grundlag af tilstedeværelsen af bestemte sproglige midler eller konfigurationer af sådanne midler.

Er det f.eks. muligt at identificere (1) som en beskrivende teksttype, fordi der er mange beskrivende adjektivsyntagmer (synligt, helt hvidt, stejlt) og verber i præsens (er, haver sig), (2) som en fortællende teksttype, fordi der er tidsadverbialer (i 1887, omkring århundredeskiftet, $i$ 1909) og handlingsverber i præteritum (lavede), og (5) som en instruerende teksttype, fordi der er mange imperativer (Hent ikke, Benyt ikke, Bevar og Udnyt)?

Visse forskere som f.eks. Bronckart et al. (1985) klassificerer teksttyperne på grundlag af et systematisk inventar af "bundter" af specifikke sproglige markører.

\subsection{Relationen mellem teksttyper og deres kommunikative funktion}

Den fjerde og sidste problemstilling vedrører relationen mellem teksttyper betragtet som bestemte tekstuelle former og så de(n) kommunikative funktion(er), afsenderen kan realisere ved hjælp af disse former.

I den allerede omtalte artikel skelner Virtanen (1992) således mellem tekstyper (former) og diskurstyper (funktioner) inden for rammerne af, hvad hun kalder en two-level model, og opstiller herefter en typologi, ifølge hvilken den fortællende teksttype er en stærk, prototypisk teksttype, der synes at være i stand til at realisere alle mulige diskurstyper (inklusive argumentation), hvorimod den argumenterende teksttype kun synes at være i stand til at realisere en enkelt diskurstype, nemlig argumentation. 


\section{Tekstlingvistik ifølge Jean-Michel Adam}

Inden vi ser nærmere på svar eller løsninger, som Jean-Michel Adams teori om teksttyper giver på de ovenfor omtalte problemstillinger, vil jeg først præsentere hans tekstlingvistiske forskning som sådan (afsnit 3.1) og give en introduktion til den teoretiske ramme, han arbejder inden for (afsnit 3.2). Af pladshensyn er det desværre ikke muligt at behandle alle aspekter af denne ellers komplekse ramme; kun de elementer, som har direkte betydning for teorien om teksttyper vil blive omtalt.

\subsection{Fra "litteraturens lingvistik" til teorien om tekstse- kvenser}

Jean-Michel Adam er professor i fransk lingvistik og leder af Forskningscentret for tekstlingvistik og diskursanalyse ved universitetet $\mathrm{i}$ Lausanne (Schweiz). Adam har været aktiv i kredsen omkring tidsskriftet Pratiques, der har sit hovedsæde i Metz i Nordfrankrig, og som er et af Frankrigs vigtigste tidsskrifter inden for tekstlingvistik. Siden midten af 70'erne har han udgivet en række værker, hvoraf det tydeligt fremgår, at hans forskning kan inddeles i to mere eller mindre komplementære dele.

Den første del af sin forskning betegner Adam selv som en lingvistisk tilgang til litterære tekster (jf. Adam 1997: 9). Hans forskning inden for dette område - og anvendelsen af den til pædagogiske formål - finder man i værker som Linguistique et discours littéraire (1976), Langue et littérature (1991a) og Le style dans la langue (1997). I modsætning til det danske forskningsmiljø, hvor sprogforskere ikke beskæftiger sig med litterære tekster og litteraturforskere ikke med sprog, er der i Frankrig en frugtbar tradition for at kombinere lingvistik og litteratur. ${ }^{5}$ Udover denne tradition, som han i en vis forstand selv har været med til at sætte i gang, påberåber Adam sig også inspiration fra den tyske tekstlingvist Harald Weinrich, der allerede i begyndelsen af 60'erne, i en af tekstlingvistikkens klassikere Tempus (1964), talte om en "litteraturens lingvistik", hvorved han forstod en applikation af bestemte lingvistiske metoder på litterære tekster med henblik på analyse af

5 En anden af de franske tekstlingvister eller diskursanalytikere, som har beskæftiget sig indgående med litterære tekster, er Dominique Maingueneau. Se bl.a. hans Eléments de linguistique pour le texte littéraire (1986). For en redegørelse for den pædagogiske dimension af brugen af litterære tekster i sprogundervisningen i Frankrig, se bl.a. Peytard/Moirand (1992). 
aspekter, der er interessante for såvel lingvister som litterater (jf. Weinrich 1973: 60). Adams lingvistiske tilgang til litterære tekster er for nylig mundet ud i det, som han kalder for "une reconception de la stylistique"; et projekt, der tager sit udgangspunkt i den renæssance, som stilistikken oplever i disse år i Frankrig, og som bygger på en reformulering af den klassiske modstilling mellem grammatik og stilistik eller norm og variation (se Adam 1997: 11, 24-27, 33).

Den anden del af Adams forskning udgøres af det, som jeg her, delvist $\mathrm{i}$ overensstemmelse med hans egen terminologi, har valgt at kalde for en teori om teksttyper. Forbeholdet skyldes, at Adam i langt de fleste tilfælde foretrækker at tale om tekstsekvenser. I denne artikel vil begge termer dog blive brugt som betegnelser for de samme sproglige/ tekstuelle fænomener. Adams forskning inden for dette område findes i en lang række værker udgivet fra midten af 80'erne og frem til i dag. En stor del af disse værker er helliget studiet af bestemte teksttyper, fremfor alt den fortællende og den beskrivende type, som f.eks. Le récit (1984), Le texte narratif (1985a; rev. udg. 1994), Le texte descriptif (1989) og La description (1993). To værker, nemlig Eléments de linguistique textuelle (1990) og Les textes : types et prototypes (1992), må opfattes som Adams hovedværker, for så vidt de giver den mest detaljerede behandling af såvel den overordnede teoretiske ramme som teorien om teksttyper.

I sine seneste udgivelser som f.eks. har Adam især koncentreret sig om studiet af argumentation se også (Adam 1996).

\subsection{Den teoretiske ramme}

Selv om der i løbet af årene er sket visse teoretiske forskydninger, som jeg skal vende tilbage til senere i dette afsnit, og selv om visse inspirationskilder ${ }^{6}$ og visse begreber ${ }^{7}$ er blevet forladt eller skiftet ud undervejs, har Jean-Michel Adam arbejdet inden for stort set den samme teoretiske ramme siden midten af 80 'erne. De første samlede fremstil-

6 Det gælder f.eks. Egon Werlichs værker Typologie der Texte (1975) og A Text Grammar of English (1976), som Adam er inspireret af i sine første artikler om teksttyper (jf. Adam 1992: 8). Se Kjersti Fløttums artikel i dette nummer.

7 Det gælder f.eks. Teun van Dijks begreb om superstrukturer, som Adam er inspireret af i sine første artikler, men som han forlader fra og med Les textes: types et protoptypes, fordi begrebet efter hans opfattelser betegner tekstuelle enheder, som er for vage (jf. Adam 1992: 32-33). Der henvises igen til Kjersti Fløttums artikel i dette nummer. 
linger af denne ramme går tilbage til Adam (1986: 6), Adam (1987: 52) og Adam/Petitjean (1989: 80), men rammen har dog været under stadig finjustering lige siden. Det fremgår bl.a. af Eléments de linguistique textuelle (1990) og Les textes: types et prototypes (1990), hvor man kan finde den mest omfattende og detaljerede fremstilling af den teoretiske ramme (se Adam 1990: 21 og Adam 1992: 17), men de anvendte skemaer er karakteristisk nok ikke alene forskellige i deres udformning, men tjener tillige to forskellige formål. Jeg vil i dette afsnit først og fremmest støtte mig til Adam (1992) og delvist til Adam (1991b).

Det, som straks springer i øjnene ved Adams teoretiske ramme, er, at den integrerer begreber og elementer fra mange forskellige teorier - et karakteristisk træk ved hans tekstlingvistiske forskning i det hele taget. Blandt hans inspirationskilder skal især nævnes den russiske sprogforsker og sprogfilosof Mihail Bakhtine, som Adam er inspireret af på flere centrale punkter. Det fremgår f.eks. af Adams lingvistiske tilgang til litteraturen og den ovenfor omtalte reformulering af stilistikken, hvor han er inspireret af Bakhtines idé om komplementaritet mellem grammatik og stilistik (Bhaktine 1984: 272; Adam 1997: 29-32). Og det fremgår af Adams teori om teksttyper, der bl.a. bygger på Bakhtines distinktion mellem primare og sekundare diskursgenrer (Bakhtine 1984: 287; Adam 1992: 12), hvoraf de første repræsenterer fremstillingsformer i såvel dagligsprog som litteratur, mens de andre repræsenterer tekstgenrer (f.eks. de litterære genrer). Af andre vigtige inspirationskilder skal nævnes den franske hermeneutiske filosof Paul Ricoeur, hvis begreb om konfiguration (Ricoeur 1983-85) ligger til grund for den komponent i Adams teoretiske ramme, som han kalder for den pragmatisk-konfigurationelle dimension.

Imod en sådan integrerende tilgang kan man naturligvis indvende, at den risikerer at komme til at forene teorier og begreber, der i sidste instans viser sig at være uforenelige, og at den dermed ender i eklekticisme. Imod en ellers udbredt tendens inden for sprogvidenskaberne til igen og igen at opfinde nye begreber og påberåbe sig nye paradigmer fremhæver Adam dog, at tekstlingvikken i dag er så stærk en disciplin, at den ikke løber nogen risiko for at ende i eklekticisme: "la linguistique textuelle peut aujourd'hui se définir comme un ensemble théorique assez puissant pour intégrer sans éclectisme une telle tradition et un tel héritage. Savoir hériter, ce sera savoir reformuler des acquis sans confusion et avec assez de modestie pour ne pas prétendre abusivement au 
changement radical de paradigme" (Adam 1990: 9 - min fremhævelse). ${ }^{8}$

De væsentligste teoretiske forskydninger, som har haft betydning for udformningen af Adams teoretiske ramme, finder sted i begyndelsen af 90'erne, fremfor alt i Adam (1992), hvor to nye metodiske grundprincipper introduceres. For det første indfører Adam en modulær tilgang til sproget og teksttyperne: "La complexité textuelle est observable et abordable d'un point de vue typologique à la seule condition d'adopter un point de vue modulaire" (Adam 1992: 16). Adam betragter således en tekst som en konfiguration, der er styret af forskellige relativt autonome moduler eller undersystemer, der konstant interagerer med hinanden (jf. Adam 1992: 20, 21). For det andet inddrager Adam teorien om prototyper. Teksterne opfattes som placeret på en typikalitetsgradient, der går fra de centrale repræsentanter til de perifare repræsentanter for det prototypiske skema for en given teksttype (jf. Adam 1992: 28, 30).

Man kan præsentere Adams teoretiske ramme på en overskuelig måde ved at tage udgangspunkt $i$ hans definitioner af begreberne diskurs, udsagn og tekst.

Ved diskurs forstår Adam en form for sproglig adfærd eller diskursiv praksis, som henhører under en diskursiv formation, der f.eks. kan være journalistisk, politisk, litterær eller religiøs, og inden for hvilken der produceres bestemte diskursgenrer. Diskursen udgør i den forstand et tværvidenskabeligt objekt, der både omfatter sociokulturelle og sproglige aspekter. Adams teori om teksttyper begrænser sig dog udelukkende til de sidstnævnte aspekter.

Ved udsagn forstår Adam den talte eller skrevne "tekst" i materiel forstand, dvs. et empirisk objekt, som kan iagttages og beskrives. ${ }^{9}$ Ved tekst forstår Adam derimod et abstrakt objekt, der per definition er kon-

8 Adam henviser i denne forbindelse til Francis Jacques' artikel "Le mouvement du texte", hvori en tilsvarende betoning af muligheden for teoretisk integration kommer til udtryk: "L'heure de la mise au feu successive des grandes hypothèses de travail est passée. Celle de la réintégration a sonné. [...] Il est clair que la meilleure tradition interthéorique pour l'accueillir est la plus puissante et la plus intégrative, j'entends sans éclectisme, des programmes de recherche locaux" (1987: 76).

9 Jeg har bevidst valgt at oversætte den franske term énoncé med udsagn og ikke, som det er mere udbredt i dag, med ytring, eftersom termen her efter min opfattelse dækker over noget andet og mere end den lingvistiske pragmatiks ytring. For en diskussion af dette oversættelsesproblem, se Nølke (1989: 13). 
strueret, og som har til formål at give en teoretisk forklaring på udsagnets kompositionelle struktur (Adam 1992: 15). Adams skelnen mellem udsagn og tekst svarer kort sagt til det, som jeg andetsteds har kaldt en metodologisk skelnen, hvorimod hans skelnen mellem udsagn og diskurs snarere svarer til en empirisk skelnen (jf. Frandsen 1996: 128-129).

Som det fremgår af fig. 1, omfatter teksten (defineret som abstrakt objekt) i alt fem forskellige organisationsplaner fordelt på to grupper kaldet henholdsvis rakke af propositioner og pragmatisk konfiguration. I overensstemmelse med den valgte modulære tilgang opfatter Adam disse organisationsplaner som relativt autonome moduler eller undersystemer. ${ }^{10}$

Fig. 1. Den teoretiske ramme for Adams teori om teksttyper

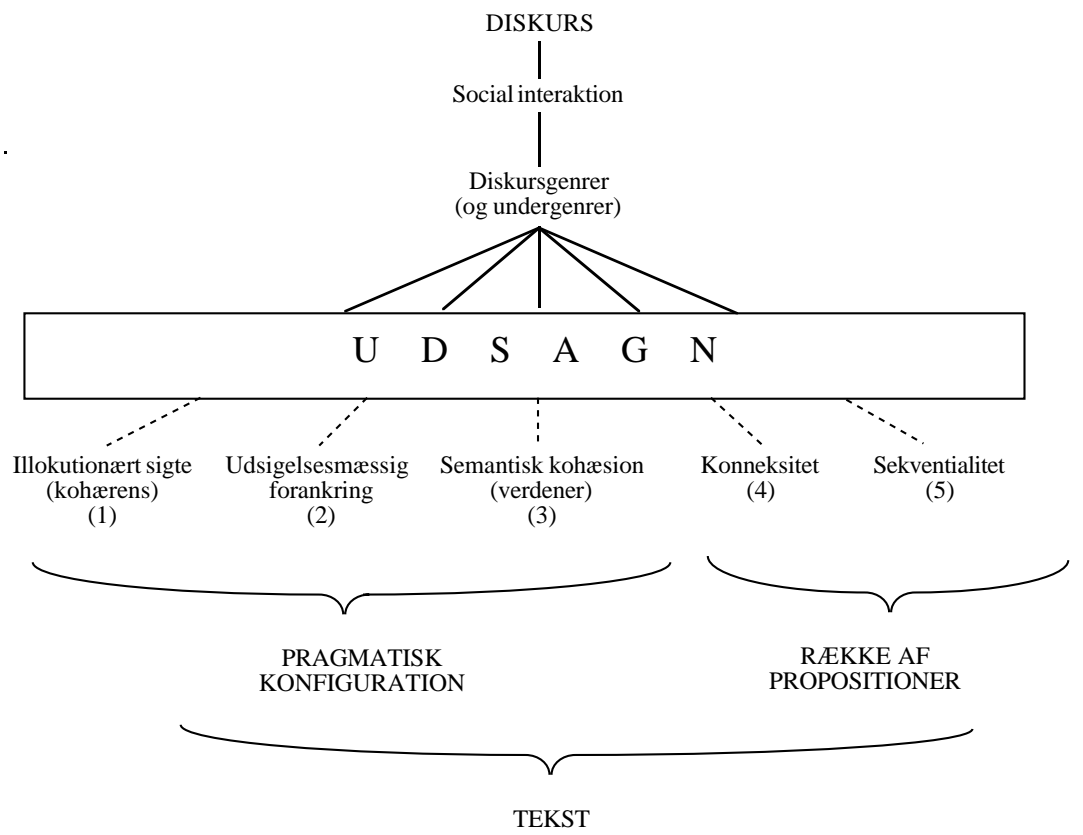

Kilde: Adam (1992: 17)

10 Adam (1990) skelner imellem seks tekstuelle organisationsplaner, nemlig kader, semantiske rum, segmentering, periode eller parentesering, sekvenser og den pragmatisk-konfigurationelle dimension. Se Frandsen (1996) for en anvendelse af disse organisationsplaner i analysen af en avistekst. 
Under den pragmatiske konfiguration finder vi følgende tre tekstuelle organisationsplaner:

\section{Det illokutionære sigte (kohærens)}

- Teksten beskrives på dette plan som bestående af en række af diskurshandlinger, der til sammen udgør en makrodiskurshandling, og som havende et bestemt formål, nemlig at påvirke en (individuel eller kollektiv) modtagers forestillinger, overbevisninger og/eller adfærd. Enhver tekst har med andre ord det, som Adam kalder en argumentativ orientering.

- Det er endvidere modtagerens interpretation af det illokutionære sigte eller afsenderens intention, som skaber sammenhæng i teksten. Kohærens er altså ikke en sproglig egenskab ved teksten, men resultatet af en interpretativ aktivitet.

\section{Den udsigelsesmassige forankring}

- Adam taler om tekstens globale udsigelsesmæssige forankring, der giver teksten, hvad han kalder for "une certaine tonalité énonciative d'ensemble", f.eks. som mundtlig diskurs, skriftlig diskurs, aktuel diskurs ("discours") eller ikke-aktuel diskurs ("histoire").

- Adam taler desuden om "la prise en charge des propositions", det forhold, at et udsigelsessubjekt "overtager" eller gøres ansvarligt for det sagte - et fænomen, som Adam forestiller sig man kan analysere ved hjælp af et begreb om semantiske rum (beslægtet med Martins begreb om univers de croyance og Fauconniers begreb om mentale rum) samt ved hjælp af Ducrots polyfoniteori.

\section{Den semantiske kohæsion (verdener)}

- Dette plan omfatter tekstens tematiske makrostruktur, dens globale tema (topic) eller dens semantisk-referentielle dimension, hvorved der repræsenteres en verden i teksten.

- I modsætning til kohærens (eller den kontekstuelle relevans) definerer Adam kohæsion som et kotekstuelt fænomen, der bl.a. kan analyseres ved hjælp af Greimas' og Rastiers begreb om semantisk isotopi.

Under rækken af propositioner finder vi følgende to tekstuelle organisationsplaner:

\section{Konneksitet}

- Dette plan omfatter såvel den enkelte propositions morfosyntaktiske struktur samt den mikrotekstuelle sammenhæng fra proposition til proposition, der på én og samme tid sikrer kontinuitet (ved forskellige former for gen(op)tagelse) og progression i teksten.

- I modsætning til kohærens og semantisk kohæsion taler Adam her om konneksitet, hvorunder han også placerer fænomener som segmentering 
(inddelingen af teksten i typografisk afgrænsede enheder, af Adam kaldet "unités vi-lisibles") og parentesering (gruppering af propositioner ved hjælp af konnektorer og organisatorer).

\section{Sekventialitet}

Det femte og sidste organisationsplan repræsenterer det modul eller undersystem, som udgør Adams teori om teksttyper.

Adams teori om teksttyper bygger på en række grundantagelser. For det første er det Adams opfattelse, at hele tekster udgør alt for heterogene størrelser til, at de kan underkastes typologisk reduktion; der kan kun opstilles en typologi for tekstsekvenser, altså for de mindre dele, som en tekst består af, og som er placeret på et organisationsplan mellem de enkelte sætninger, hvormed en tekst realiseres, og teksten som helhed. Derfor kan Adam også hævde, at han faktisk bryder med hele ideen om en teksttypologi: "le modèle de la structure compositionnelle des textes que je propose - et qui rompt avec l'idée même de "typologie des textes" (Adam 1996: 31). Som det vil fremgå af det følgende, forhindrer dette dog på ingen måde Adam i at tale om tekstgenrer.

For det andet hævder Adam, at tekster og sekvenser har en hierarkisk grundstruktur. En tekst $(\mathrm{T})$ defineres således som en kompleks hierarkisk struktur, der består af $n$ antal fuldstændige eller elliptiske sekvenser af samme eller forskellig type (Adam 1992: 34). En sekvens defineres på tilsvarende vis som bestående af $n$ antal makropropositioner, der så igen består af mikropropositioner. Det hierarkiske forhold mellem tekst, sekvens og (makro)proposition er illustreret i fig. 2.

\section{Fig. 2. Tekstens hierarkiske grundstruktur ${ }^{11}$}

[\# T \# [Sekvens(er) [makroproposition(er [proposition(er]]]]

Kilde: Adam (1992: 30)

Det er desværre ikke muligt inden for rammerne af denne artikel at præsentere de prototypiske skemaer, som Adam opstiller for hver enkelt teksttype. For at man dog kan danne sig en idé om, hvordan en teksttypes interne organisation tager sig ud, skal jeg på grundlag af (1) ganske kort redegøre for de procedurer (eller makrooperationer), der

11 Tegnet \# markerer tekstens "grænser”, dvs. dens begyndelse og/eller afslutning f.eks. i form af en paratekst. 
ifølge Adam ligger til grund for den beskrivende teksttype. Der er tale om følgende procedurer:

\section{Forankring}

- Den procedure, hvorved den beskrivende sekvens forankres referentielt, og som angiver, hvad teksten vil handle (eller har handlet) om; forankringen udtrykkes sprogligt med det, som Adam kalder en tema-titel, og som skaber semantisk kohæsion

- Analyse af (1): forankring ved tema-titlen Mont Ventoux

\section{Reformulering}

- Den procedure, hvorved den oprindelige tema-titel ændres; sprogligt kan denne ændring udtrykkes på mange måder, f.eks. ved en apposition eller ved konstruktioner af typen N1 kaldes/hedder N2

- Analyse af (1): reformulering ved et andet Fuji Yama og et forvokset muldvarpeskud

\section{Aspektualisering}

- Den procedure, som udgør selve grundlaget for beskrivelsen, og som består i en inddeling af den forankrede helhed i dele (Bp DEL - synekdoke) og $\mathrm{i}$ en beskrivelse af egenskaber ved denne helhed eller disse dele, deres form, størrelse, farve, antal osv. (Bp EGENSK)

- Analyse af (1): aspektualisering ved f.eks. (bjerget som helhed) som nasten altid er synligt eller er der ellers stejlt med stigninger fra 6 til 14\% eller (del af bjerget: det forste stykke op mod toppen) er altid helt hvidt

\section{Forbindelse}

- Den procedure, hvorved den beskrevne helhed (eller del) sættes i forbindelse med noget andet, det være i form af angivelse af et bestemt sted eller tidsrum (metonymi), en sammenligning eller en metafor

- Analyse af (1): forbindelse ved f.eks. tidsangivelse fra december til april eller sammenligning/metafor en hvid kalkstens $\phi r k e n$ uden vegetation

\section{Tematisering}

- Den procedure, hvorved en del af den beskrevne helhed (udvalgt ved aspektualisering) vælges som grundlag for en ny sekvens, der så igen kan underkastes aspektualisering og forbindelse

- Analyse af (1): det eksempel, som blev anført under aspektualisering - det forste stykke op mod toppen samt beskrivelsen af dette stykke om vinteren og sommeren - kan også betragtes som et eksempel på tematisering (den referentielle forankring kan således betragtes som den grundtematisering, som alle efterfølgende tematiseringer må tage udgangspunkt i) 
Adam (1992: 84) giver følgende repræsentation (fig. 3) af det prototypiske skema for den beskrivende teksttype med alle de ovennævnte procedurer eller makrooperationer:

\section{Adams svar på de centrale problemstillinger inden for forskning i teksttyper}

I denne sektion skal vi vende tilbage til de fire centrale problemstillinger inden for forskningen i teksttyper, som blev omtalt i sektion 2, og se nærmere på de svar eller løsninger, som Jean-Michel Adams teori kan give på disse problemstillinger.

Fig. 3. Det prototypiske skema for den beskrivende teksttype

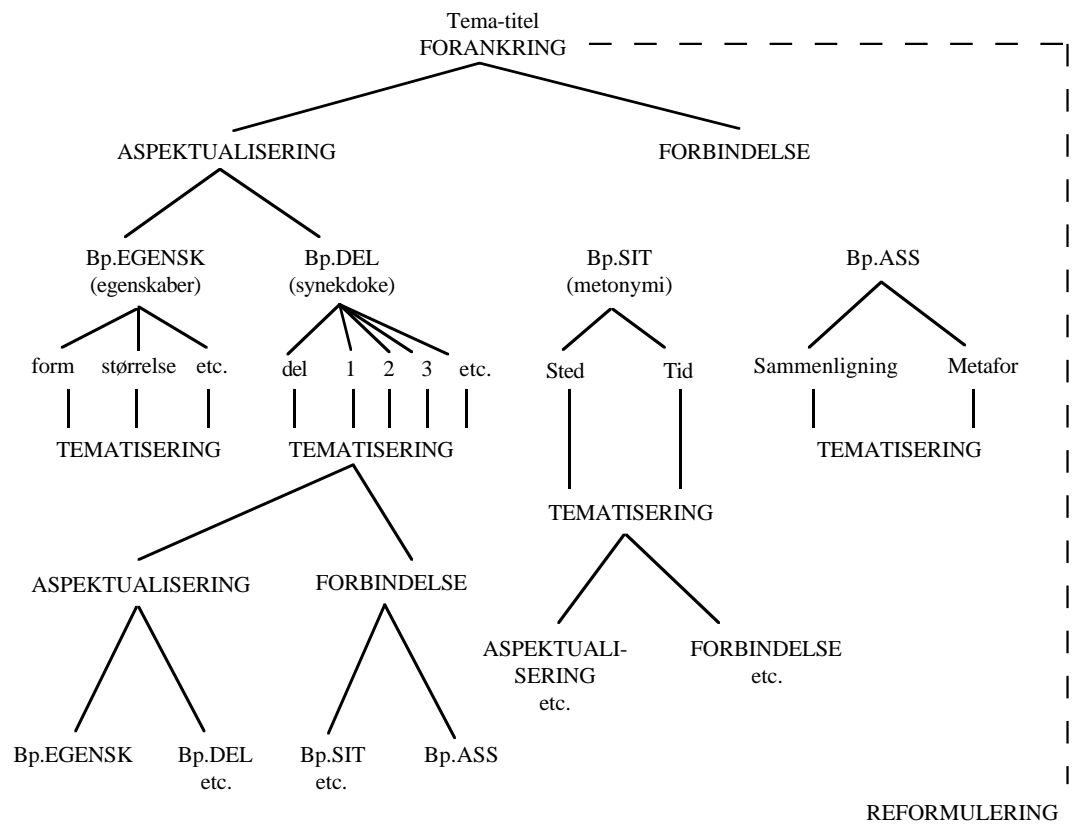

Kilde: Adam (1992: 84) 


\subsection{Antallet af teksttyper}

Spørgsmålet om, hvor mange teksttyper det er muligt at identificere, er uden tvivl det område, hvor Jean-Michel Adams teori har udviklet sig mest. Det er Adams hypotese - som det er mange andre tekstlingvisters hypotese - at der eksisterer et lille antal sekventielle grundtyper, men hvor lille dette antal er, varierer til gengæld meget.

I et af sine første fors $ø \mathrm{~g}$ på at opstille en teori om tekstsekvenser, artiklen "Quels types de textes?" fra 1985, opstiller Adam ikke mindre end otte forskellige teksttyper. Disse otte typer betragtes på den ene side som afledte af bestemte diskurshandlinger og på den anden side som (fortrinsvis) aktualiserede i bestemte tekstgenrer. Fig. 4 sammenfatter forholdet mellem teksttype, diskurshandling og tekstgenre. 
Fig. 4. Forholdet mellem teksttype, diskurshandling og tekstgenre if $\emptyset$ ge Adam (1985)

DISKURSHANDLING

TEKSTTYPE

TEKSTGENRE

\begin{tabular}{|c|c|c|}
\hline At fremsætte "gørens-udsagn" & Den fortællende type & $\begin{array}{l}\text { F.eks. } \\
\text { Journalistiske genrer som } \\
\text { reportage eller le fait divers } \\
\text { Litterære genrer som roman eller } \\
\text { novelle } \\
\text { Andre genrer som eventyr, } \\
\text { historiebøger, lignelser, } \\
\text { fortællende reklamer, politisk } \\
\text { fortælling, film, tegneserier, } \\
\text { morsomme historier }\end{array}$ \\
\hline At fremsætte "værens-udsagn" & Den beskrivende type & $\begin{array}{l}\text { F.eks. } \\
\text { inventar, turistguide, ordbog, } \\
\text { leksikon, krydsord }\end{array}$ \\
\hline $\begin{array}{l}\text { At forklare (begreber) eller få } \\
\text { nogen til at forstå noget }\end{array}$ & Den forklarende type & $\begin{array}{l}\text { F.eks. } \\
\text { didaktisk diskurs, videnskabelig } \\
\text { diskurs }\end{array}$ \\
\hline $\begin{array}{l}\text { At overbevise (overtale, få nogen } \\
\text { til at tro noget) }\end{array}$ & Den argumenterende type & $*$ \\
\hline Atbeordre & Den påbydende type & $\begin{array}{l}\text { F.eks. } \\
\text { opskrift, monteringsvejledning, } \\
\text { regulativer }\end{array}$ \\
\hline At forudsige & Den forudsigende type & $\begin{array}{l}\text { F.eks. } \\
\text { profeti, vejrudsigt, horoskop }\end{array}$ \\
\hline At spørge (f.eks.) & Den konversationelle type & $\begin{array}{l}\text { F.eks. } \\
\text { interview, dialog }\end{array}$ \\
\hline$* *$ & Den retoriske type & $\begin{array}{l}\text { F.eks. } \\
\text { digt, prosadigt, sang, bøn, } \\
\text { slogan, ordsprog, mundheld, } \\
\text { maksime, graffiti og "toute } \\
\text { pratique du titre" }\end{array}$ \\
\hline
\end{tabular}

* Her taler Adam meget vagt om argumenterende "undergenrer"

** Adam nævner ingen diskurshandling i forbindelse med den retoriske teksttype.

Adam (1985) omtaler de fem første af disse otte typer som "klassiske", hvad der i denne sammenhæng blot betyder, at de svarer til de fem ty- 
per, som Werlich har opstillet. At han dog ikke bare gentager Werlichs klassifikation fremgår af, at han for det første rubricerer den fremstillende teksttype under den forklarende type og for det andet omdefinerer den instruerende teksttype som den påbydende type.

Redegørelsen for de nævnte teksttypers interne organisation i Adam (1985) lider dog under, at der er blevet byttet om på skemaerne (mere præcist repræsentationen af superstrukturen) for henholdsvis den fortællende og den beskrivende type, samt at man ikke får en forklaring på, hvorfor den fortællende teksttype i skemaerne er forbundet med interaktion som makrodiskurshandling og den beskrivende teksttype med en argumentativ funktion som makrodiskurshandling (se Adam 1985: 41).

Allerede i de efterfølgende artikler sker der en langsom, men systematisk reduktion af antallet af teksttyper. I Adam (1986) er antallet skåret ned til syv, nemlig 1) den fortællende, 2) den beskrivende, 3 ) den argumenterende, 4) den fremstillende-forklarende, 5) den påbydende-instruerende, 6) den konversationelle-dialogale og 7) den retoriske-poetiske teksttype. Som det fremgår, er den forudsigende teksttype gledet ud. Adam antager dog stadig som hypotese, at der findes en forudsigende type, aktualiseret i tekstgenrer som f.eks. horoskoper, vejrudsigter og profetier. Der er også sket en interessant terminologisk udvikling: der tales f.eks. nu om en "fremstillende-forklarende" type. At der langt fra er tale om en veletableret klassifikation, fremgår også af Adams tøven med at udpege brevgenren som en teksttype for sig, for så vidt den udgør en mono-styret underkategori af den konversationelle-dialogale type (jf. Adam 1986: 17).

I Adam (1987) skelnes der stadig mellem syv teksttyper, men nogle af typerne har enten skiftet navn eller status. Dette gælder f.eks. den fremstillende-forklarende teksttype, der nu blot kaldes fremstilling, og hvorunder der opereres med to undertyper, nemlig den forklarende undertype og beskrivelse af eksperiment (jf. Adam 1997: 25). Adam fremhæver dog selv, at han ikke giver nogen begrundelse for "la limitation de l'énumération" (ibid.).

Fælles for de nævnte artikler er, at inspirationen fra van Dijks begreb om skematiske superstrukturer stadig er meget tydelig, og at nogle af teksttyperne ligger betænkelig tæt op af tekstgenrer (se fig. 4).

I Eléments de linguistique textuelle (1990) skelner Adam mellem kun seks teksttyper, nemlig den fortællende, den beskrivende, den forklarende-fremstillende, den argumenterende, den instruerende-påby- 
dende og den konversationelle-dialogale type (Adam 1990: 85). Den retoriske teksttype er ikke længere med, fordi den ifølge Adam ikke kan sammenlignes med de andre typer, hvad angår den sekventielle hierarkiske struktur. Den retoriske eller poetiske dimension betragtes i stedet som et "overfladefænomen", der styres af et særligt kompositionsprincip (Adam 1992: 85), og som "un mode de planification qui vient se superposer à une séquentialité d'un des six types précédents" (Adam 1990: 90).

I Les textes: types et prototypes (1992) når Adam frem til den udgave af sin klassifikation, der omfatter det laveste antal teksttyper, og som siden da har ligget ret fast (også hvad angår terminologien). Der opereres nu kun med i alt fem teksttyper: fire mono-styrede typer (kun én afsender), nemlig fortælling, beskrivelse, forklaring og argumentation, og en poly-styret type (mere end én afsender), nemlig konversation.

Der skal knyttes et par kommentarer til denne nye klassifikation. Af positiv kritik skal nævnes, at Adam selv opstiller som overordnet princip, at man skal operere med så få prototyper som muligt (Adam 1992: 98). Han arbejder med andre ord ud fra en slags "økonomiprincip". Der er flere eksempler i Les textes: types et prototypes på, hvordan dette princip føres ud i livet. F.eks. foreslår Adam, at den teksttype, som ofte går under betegnelsen den procedurale (eller programmerende) teksttype, og som han tidligere selv har kaldt for den påbydende eller instruerende teksttype (jf. ovenfor), betragtes som en særlig form for beskrivende teksttype, mere præcist som en beskrivelse af handlinger (Adam 1992: 95-97). Adam opererer heller ikke med en fremstillende-informerende teksttype, men betragter derimod denne som en encyklopædisk diskursgenre, der bygger på enten beskrivende eller forklarende sekvenser (Adam 1992: 128).

Af negativ kritik skal nævnes, at det ikke er alle fem teksttyper, som er lige gennemarbejdede. Mens der opstilles prototypiske skemaer for den fortællende (Adam 1992: 57), den beskrivende (Adam 1992: 84), den forklarende (Adam 1992: 118) og den argumenterende teksttype (Adam 1992: 132), synes dette ikke at være tilfældet for den dialogale type. Adam henviser dog selv til, at aktualiseringen af den dialogale prototype er den mest "smidige" (Adam 1992: 196). 


\subsection{Relationen mellem teksttyper inden for samme tekst}

Relationen mellem teksttyper inden for samme tekst er også et spørgsmål, som indtager en central plads i Adams teori om teksttyper, hvor der konstant sættes fokus på teksternes heterogenitet: "Le texte est une structure séquentielle fondamentalement hétérogène" (Adam 1990: 117). Det er som allerede omtalt netop denne heterogenitet, som er årsagen til, at Adam anser det for umuligt at opstille en typologi på grundlag af hele tekster; kun inden for de enkelte moduler i den teoretiske ramme, og især inden for sekvens-modulet, kan der opstilles typologier (jf. Adam 1992: 16-17).

Mens Adam (1985) endnu kun meget vagt og kortfattet taler om heterogenitet og dominans, opstilles der allerede i Adam (1987) en oversigt over de mulige relationer mellem teksttyper inden for samme tekst; en oversigt, som i øvrigt ligger fast herefter, og som man derfor genfinder i både Adam (1990) og Adam (1992).

Inden for gruppen af homogene tekster skelner Adam imellem:

- Tekster, som kun består af én sekvens

Som Adam bemærker, er der ved disse tekster i virkeligheden kun tale om kvasi-homogenitet, for så vidt der meget ofte vil optræde f.eks. evaluative propositioner i f.eks. en beskrivende tekstsekvens.

- Tekster, som består af et bestemt antal (n) sekvenser af samme type Under denne gruppe af tekster skelner Adam igen imellem en a) linear rakke af sekvenser af samme type og b) indskydning af sekvenser af samme type.

Inden for gruppen af heterogene tekster, hvor der per definition jo er repræsenteret tekstsekvenser af forskellig type, skelner Adam mellem:

- Indskydning af sekvenser af forskellig type

I dette tilfælde skelner Adam mellem den indskudte sekvens og den indskydende sekvens efter følgende princip: [indskydende sekvens [indskudt sekvens] indskydende sekvens].

- Sekventiel dominans

I dette tilfælde er der tale om en blanding af sekvenser af forskellig type efter følgende princip: [dominerende sekvens > domineret sekvens].

Lad os kort se på et konkret eksempel på kompositionel heterogenitet $\mathrm{i}$ tekster. (6) tilhører den journalistiske genre, som nogle vil kalde for portrætinterview og andre for feature. (6) er desuden skrevet i den 
journalistiske form, der kaldes for new journalism, og som er karakteriseret ved, at journalisten skildrer sin historie ud fra sin egen synsvinkel, dvs. som aktør i historien (for en nærmere redegørelse, se Rehfeld/ Therkelsen 1996).

\section{(6) Manden med fodboldforstanden}

Min førnævnte mor har altid syntes, at Tommy Troelsen er sådan en pæn mand. Og fra sin fattige barndom kan hun erindre, at Tommy Troelsen også var sådan en pæn dreng, når han stod på gaden i Nykøbing Mors og sparkede en bold op ad en husmur, hvilket han stort set gjorde dagen lang. En pæn, men genert dreng.

Beskrivelsen passer åbenbart endnu, for Troelsen går meget op i, hvad det her interview-halløj nu skal bruges til:

- Forleden blev jeg ringet op af Billed-Bladet. De sagde, at de lavede sådan noget, der hed Hjemme hos de kendte, og sådan én mente de åbenbart, at jeg var. Men den slags vil jeg altså ikke være med til. Det kommer sgu da ikke andre mennesker ved, hvordan jeg bor!

Vel gør det da ej. Derfor kunne jeg da heller ikke drømme om at fortælle nogen, at Tommy Troelsen også bor pænt - kun en lang aflevering fra Frederiksbergs bedste butiksstrøg - i en ordentlig kasse af et hus fra før århundredeskiftet med tre stuer, hvoraf de to er en suite. Jeg skal også afholde mig fra at beskrive de lyse omgivelser med højt til stukloftet, non-figurativ kunst på væggene og godt med bøger (ikke kun bogklub) i reolerne. Ligesom det heller ikke kommer nogen ved, at Tommy Troelsen og hans kone Jonna, som har været gift i over 30 år, er indehavere af en hvid- og brunstribet sofa, tre læderlænestole med vippefunktion samt et temmelig stort kakkelbord.

Nej, jeg vil nøjes med at skrive, at fodboldekspertens hjem virker lige så pænt, hyggeligt og ordentligt som ham selv. Og se, om hans ordenssans ikke også manifesterer sig i TV-Byen, 2860 Søborg, hvor han bestyrer DRs fodboldarkiv. Til stor glæde for kollegerne, som tit låner videobånd fra arkivet:

- Men journalister er altså nogle rodehoveder! De bånd ligger tit og drukner rundt omkring på skrivebordene, siger Tommy Troelsen og tilføjer alvorligt: 
- Det kan godt irritere mig en del!

(Uddrag af portrætinterview i Den ultimative 98 VM-guide - tillæg til dagbladet Politiken)

Hvis vi for overskuelighedens skyld blot koncentrerer os om beskrivelsen af Tommy Troelsens hus og hjem, så kan vi konstatere, at denne beskrivende sekvens for det første er indskudt i en konversationel sekvens, der kan karakteriseres som elliptisk, for så vidt journalistens bekræftelse af TTs udtalelse "Det kommer sgu da ikke andre mennesker ved, hvordan jeg bor!" er "narrativiseret" og forskudt tidsmæssigt, og at den for det andet selv indeholder en slags argumenterende propositioner, der som tekstplan nok underst $\varnothing$ tter beskrivelsen, men som alligevel er domineret af den: Derfor kunne jeg jeg heller ikke drømme om [...]. Jeg skal også afholde mig fra [...]. Ligesom det heller ikke kommer nogen ved [...]. Nej, jeg vil nфjes med at skrive [...]. Vi får således følgende struktur med både indskydning og dominans for denne del af teksten:

[konversationel sekvens [beskrivende sekvens > argumenterende sekvens] konversationel sekvens]

Men analysen kan naturligvis føres langt videre, da også den indskydende konversationelle sekvens er indskudt i en sekvens af en anden type.

\subsection{Relationen mellem teksttyper og de sproglige midler, hvormed disse realiseres}

Muligheden for at identificere en bestemt teksttype på grundlag af tilstedeværelsen af bestemte sproglige midler er - som det fremgår af følgende citat - ikke et spørgsmål, som Adam finder relevant for forskningen i teksttyper på nuværende tidspunkt: "Dans l'état actuel de nos connaissances, il ne me paraît pas pertinent de tenter d'énumérer des marques de surface dont le repérage suffirait pour affirmer que l'on est en présence d'une séquence narrative" (Adam 1992: 71). Ikke desto mindre er der i hans artikler og bøger spredte ansatser til et svar på dette spørgsmål.

I Adam (1985) er der fokus på viden om tekstsekvenser som en del af sprogbrugerens tekstuelle kompetence, og der tages udgangspunkt i 
en inferentiel model for modtagerens forståelse af udsagn. De sproglige midler opfattes i denne forbindelse som en række "indices de surface", der får modtageren til at udkaste en hypotese om, at der er tale om den eller den type af sekvens. Med udgangspunkt i det franske sprog giver Adam følgende eksempler på relationer mellem sproglige midler og teksttyper (fig. 5).

Fig. 5. Relationen mellem sproglige midler og teksttyper

TEKSTTYPE

\begin{tabular}{|l|l|}
\hline Den fortællende type & Mange passé simples \\
\hline Den beskrivende type & Mange imparfaits \\
\hline Den argumenterende type & Særlige konnektorer som f.eks. mais og puisque \\
\hline Den fremstillende type & Særlige konnektorer som f.eks. car og parceque \\
\hline Den instruerende type & Mange imperativer eller handlingsverber i infinitiv \\
\hline
\end{tabular}

Selv om Adam (1992: 30) fremfører, at de sproglige markører styrker genkendelsen af de prototypiske skemaer, understreger han, at en enkelt sproglig markør - f.eks. brugen af handlingsverber i le passé simple hverken udgør en nødvendig eller tilstrækkelig betingelse for identifikationen af en bestemt teksttype (i dette tilfælde den fortællende type)(jf. Adam 1992: 71). Der kan jo også bruges historisk præsens, og tilstedeværelsen af handlingsverber er også kendetegnende for beskrivelsen af handlinger. Adam forklarer dette fravær af en direkte relation mellem teksttyper og sproglige midler med en henvisning til modulariteten: "Cette modularité est certainement responsable du fait que l'on ne puisse assigner à chaque type de séquence une distribution très stricte de marques morpho-syntaxiques" (Adam 1992: 16). 
Til gengæld forestiller Adam sig, at det er muligt at udpege bestemte konfigurationer af sproglige markører som karakteristiske for bestemte teksttyper, f.eks. for den fortællende teksttypes vedkommende: en bestemt vekslen mellem le passé simple og l'imparfait og høj frekvens af pronominale anaforer, som Adam opfatter som "un des indices formels les plus caractéristiques de la séquence narrative" (Adam 1992: 71).

\subsection{Relationen mellem teksttyper og deres kommunikative funktion}

Spørgsmålet om relationen mellem teksttyper og deres kommunikative funktion er heller ikke et spørgsmål, som Adam har viet særlig stor opmærksomhed.

I Adam (1985) skelnes der inden for tekstens globale organisation mellem tre gensidigt afhængige dimensioner: a) den pragmatiske dimension, hvor teksten eller sekvensen udfører en makrodiskurshandling, b) det globale indhold eller den semantiske makrostruktur og c) den globale skematiske dimension eller den tekstuelle superstruktur. I sin redegørelse for henholdsvis den fortællende og den beskrivende teksttype tildeler Adam disse to sekvenser to forskellige makrodiskurshandlinger: interaktion ved den fortællende type og argumentativ funktion ved den beskrivende type, men vi får som tidligere nævnt ingen forklaring på, hvorfor der er tale om netop disse to makrodiskurshandlinger, og hvorfor det kun er beskrivelsen, som har en argumentativ funktion; de andre teksttyper får heller ikke tildelt nogen makrodiskurshandling.

I Adam (1990) og (1992) videreudvikles ideen om makrodiskurshandling i takt med, at den teoretiske ramme udbygges. Som omtalt i afsnit 3.2, under den pragmatiske konfiguration og mere præcist under tekstens illokutionære sigte, hævder Adam, at enhver tekst har en argumentativ orientering, nemlig at påvirke en (individuel eller kollektiv) modtagers forestillinger, overbevisninger og/eller adfærd (jf. Adam 1990: 103 og Adam 1992: 21-23). Med tekst skal her ikke kun forstås hele tekster, men også sekvenser. Dette indebærer, at de fem eller seks teksttyper, som Adam opererer med på dette tidspunkt, alle har en argumenterende kommunikativ funktion. Adam skelner altså imellem argumentation som en bestemt teksttype og argumentation som overordnet kommunikativ funktion (jf. Adam 1992: 103). 
Adam kommer dog aldrig for alvor ind på relationen mellem teksttype og kommunikativ funktion, men nøjes med spredte bemærkninger om henholdsvis den fortællende og den beskrivende teksttypes argumentative orientering (se f.eks. Adam 1992: 61-62, 82 og 91). I forbindelse med den forklarende sekvens taler han endda under henvisning til Borel (1981) om en pragmatisk funktion, der ikke bare er argumentativ, men som består $\mathrm{i}$, at afsenderen med en forklarende sekvens kan fremstille sig selv som den objektive iagttager af kendsgerninger: "Se donner pour celui qui n'évalue pas ce dont il parle, mais qui en déploie en toute objectivité l'intelligence, tel est bien le sens de toute stratégie explicative" (Adam 1992: 134).

En anden interessant problemstilling, som også kun berøres ganske kort, er nødvendigheden af at skelne imellem teksttypernes funktion inden for teksten, især ved indskydning af en sekvens i en anden sekvens, og så den egentlige kommunikative funktion. Adam giver bl.a. et eksempel på, hvordan en fortællende sekvens kan fungere som "justification" ved indskydning i en forklarende sekvens (Adam 1992: 140141), men ud over at fremhæve, at den sekventielle model øger opmærksomheden omkring indskydningen af sekvenser af forskellig type, siger han ikke noget alment om denne problemstilling.

\section{Kritik og perspektiver}

Det er et karakteristisk træk ved Adams teori om teksttyper, at han vender tilbage til de samme problemstillinger igen og igen - og til de samme eksempler. ${ }^{12}$ Af det foregående skulle det dog gerne fremgå, at de to problemstillinger, som Adam har helliget størst opmærksomhed, er spørgsmålet om antallet af teksttyper og relationen mellem teksttyper inden for samme tekst, hvorimod Adams bidrag til behandlingen af de to andre problemstillinger, relationen mellem teksttyper og sproglige midler og relationen mellem teksttyper og deres kommunikative funktion, er noget mere beskeden. Det ville måske også have været relevant at operere med endnu en problemstilling, nemlig forholdet mellem teksttyper og tekstgenrer. Som Adam (1992: 168-194) viser, går hans

12 Et af de eksempler, som Adam er vendt tilbage til igen og igen over en periode på femten år, er reklameannoncen Mir Rose. Brassart (1990) har lavet en sammenligning af de ofte meget forskellige analyser af dette eksempel, som Adam har lavet fra 1976 til 1987. Se endvidere Adam (1992: 120-124), hvor der laves endnu en analyse af Mir Rose-teksten. 
analyser også i denne retning. Men tiden er nu inde til at se på den kritik, som er blevet rettet imod Adams teori om teksttyper.

En af hovedskikkelserne i den såkaldte Geneve-skole, Eddy Roulet, har i en artikel fra 1991 rettet en række væsentlige indvendinger imod Adams teori om teksttyper. Kritikken bygger ganske vist på ældre udgaver af teorien (Adam 1987c, 1989a og 1989b), men er dog på de fleste af punkterne stadig gyldig.

- For det første hævder Roulet, at der er tale om en typologi, som hører hjemme på et kognitivt, før-sprogligt niveau. Han tilslutter sig her Schneuwly (1987) og Bouchard (1991) i deres opfattelse af både Werlichs og Adams typologier som kognitive eller procedurale typologier (jf. Roulet 1991: 119).

- For det andet hævder Roulet, at Adams typologi blot udgør det, som han inspireret af Saussure kalder for et "repertoire" eller en "nomenklatur", dvs. en åben liste, der omfatter et variabelt antal typer. Dette medfører en vis uklarhed i klassifikationen og i betegnelserne for de enkelte teksttyper (jf. Roulet 1991: 119).

- For det tredje hævder Roulet, at de kategorier, som Adam opstiller, bygger på heterogene kriterier. Dette gælder især den konversationelledialogale teksttype og den retoriske-poetiske teksttype (jf. Roulet 1991: 120).

- Endelig anfører Roulet for det fjerde, at Adams kategorier ikke er eksklusive, dvs. at de ikke gensidigt udelukker hinanden, men tværtimod lader sig kombinere: en konversationel-dialogal type kan f.eks. udmærket være poetisk, en beskrivende eller fortællende type argumenterende osv. Efter Roulets opfattelse beskæftiger Adam sig derfor snarere med dimensioner af teksten end med egentlige typer (jf. Roulet 1991: 120).

Hvad angår den første af Roulets indvendinger, så står den i skarp modsætning til Adams egen opfattelse af sin teori som meget sprogligtorienteret. Men man kan kun give Roulet ret, når han fremhæver, at superstrukturen (eller det, som i den her behandlede 1992-version af teorien hedder det prototypiske skema) for f.eks. den beskrivende teksttype repræsenterer en analysemåde, som i sidste instans er uafhængig af de sproglige strukturer. Denne opfattelse underbygges i øvrigt også indirekte af Adams beskedne interesse for forholdet mellem teksttyper og sproglige midler (jf. afsnit 4.3). Roulet overser dog, at en del af ske- 
maet for den beskrivende teksttype, nemlig den tidligere omtalte reformulerings-procedure (beskrevet detaljeret i Adam 1990: 143-190), inddrager de sproglige strukturer på en meget direkte måde.

Hvad angår den anden indvending, så har vi set, at Adams teori ændrer sig betragteligt med hensyn til såvel antallet af teksttyper som de anvendte betegnelser (her dog i mindre grad). Når man ser på de fem teksttyper, som Adam har opereret med siden begyndelsen af 90'erne, kan man heller ikke undgå at stille spørgsmålet, om Adam er havnet i det, Bouchard (1991: 29) kalder for den "typologiske fatalitet", det forhold at forskeren enten overtager allerede eksisterende intuitive typologier eller helt afviser relevansen af at skelne imellem teksttyper og tekstgenrer. Eller for at udtrykke det på en lidt anden måde: er det $\mathrm{i}$ sidste instans kun en "tradition" eller en "arv" (fra retorikken eller stilistikken), som bestemmer antallet af teksttyper (se f.eks. Adam 1992: $5)$ ?

Hvad angår de to sidste af Roulets indvendinger, så har Adam selv fjernet den retoriske-poetiske teksttype fra sin klassifikation for i stedet at opfatte den som et særligt kompositionsprincip (jf. afsnit 4.1). Roulets indvending imod Adams behandling af den konversationelledialogale teksttype, nemlig at den har en superstruktur eller et skema, der befinder sig på et andet niveau i det diskursive hierarki, synes dog stadig at være gyldig. Det samme gælder Roulets kritik af Adams opfattelse af dominans-relationen, som han ikke mener er tilstrækkelig klart defineret.

Alt $\mathrm{i}$ alt synes der altså at være nok at tage fat på for Jean-Michel Adam i de kommende år. Hans teori har bragt den tekstlingvistiske forskning i teksttyper et pænt stykke videre, ikke mindst takket være dens fokusering på teksternes heterogenitet og sekvenserne som udgangspunkt for en typologisering, men inden for alle de fire problemstillinger, som er blevet omtalt i denne artikel, er der stadig meget at beskrive og forklare. Og den første til at være opmærksom på dette er Jean-Michel Adam selv, når han åbent henviser til den kritik, der er blevet rettet imod hans teori, og samtidig beskriver sin egen dynamiske forskning som "une recherche qui est loin d'être achevée" (Adam 1992: 8). 


\section{Referencer}

Adam, Jean-Michel (1984): Le récit. Paris: PUF, coll. "Que sais-je ?”.

Adam, Jean-Michel (1985a): Le texte narratif. Paris: Nathan. 2. revideret udg. 1994.

Adam, Jean-Michel (1985b): Pour lire le poème. Bruxelles: De Boeck.

Adam, Jean-Michel (1985c): Quels types de texte ? In Le Français dans le monde 192. 39-43.

Adam, Jean-Michel (1986): Dimensions séquentielle et configurationelle du texte. In Degrés 46-47. B1-B22.

Adam, Jean-Michel (1987a): Textualité et séquentialité. L'exemple de la description. In Langue Française 74. 51-72.

Adam, Jean-Michel (1987b): Approche linguistique de la séquence descriptive. In Pratiques 55. 3-27.

Adam, Jean-Michel (1987c): Types de séquences textuelles élémentaires. In Pratiques 56. 54-79.

Adam, Jean-Michel (1989a): Pour une pragmatique linguistique et textuelle. In Reichler, C. (éd.): L’interprétation des textes. Paris: Minuit. 183-222.

Adam, Jean-Michel (1989b): Une approche unifiée des plans d'organisation textuelle ? In Rubattel, C. (éd.): Modèles du discours. Recherches actuelles en Suisse romande. Bern: Peter Lang. 1-33.

Adam, Jean-Michel (1990): Eléments de linguistique textuelle. Liège: Mardaga.

Adam, Jean-Michel (1991a): Langue et littérature. Paris: Hachette.

Adam, Jean-Michel (1991b): Cadre théorique d'une typologie séquentielle. In Etudes de linguistique appliquée 83. 7-18.

Adam, Jean-Michel (1992): Les textes : types et prototypes. Paris: Nathan.

Adam, Jean-Michel (1993): La description. Paris: PUF, coll. "Que sais-je ?".

Adam, Jean-Michel (1996): L'argumentation dans le dialogue. In Langue française 112. 31-49.

Adam, Jean-Michel/Bonhomme, Marc (1997): L'argumentation publicitaire. Paris: Nathan.

Adam, Jean-Michel/Goldenstein, Jean-Pierre (1976): Linguistique et discours littéraire. Paris: Larousse.

Adam, Jean-Michel/Petitjean, André (1989): Le texte descriptif. Paris: Nathan. Adam, Jean-Michel/Revaz, Françoise (1996): L'analyse des récits. Paris: Seuil, coll. "Mémo".

Bakhtine, Mihail (1984): Esthétique de la création verbale. Paris: Gallimard. Beaugrande, Robert de/Dressler, Wolfgang. (1981): Introduction to Text Linguistics. London: Longman. 
Biber, Douglas (1988): Variation Across Speech and Writing. Cambridge: Cambridge University Press.

Biber, Douglas (1989): A Typology of English Texts. In Linguistics 27. 23-43.

Borel, M.J. (1981): L'explication dans l'argumentation : approche sémiologique. In Langue française 50.

Bouchard, Robert (1991): Repères pour un classement sémiologique des événements communicatifs. In Etudes de linguistique appliquée 83. 29-62.

Brassart, D.G. (1990): Retour(s) sur "Mir Rose" ou comment analyser et représenter le texte argumentatif (écrit) ? In Argumentation 4.

Bronckart, Jean-Paul et. al. (1985): Le fonctionnement des discours. Neuchâtel: Delachaux \& Niestlé.

Bronckart, Jean-Paul (1991): Perspectives et limites d'une diversification de l'enseignement du français. In Etudes de linguistique appliquée 83. 63-74.

Coste, Daniel (1991): Genres de textes et modes discursifs dans l'enseignement/apprentissage des langues. In Etudes de linguistique appliquée 83. 7588.

Etudes de linguistique appliquée 83 (1991): temanummer om "Textes, discours, types et genres".

Fafner, Jørgen (1977): Retorik. Klassisk og moderne. København: Akademisk Forlag.

Frandsen, Finn (1995a): Kategoriseringsmodeller, typer af kriterier og gyldighedsområder - de tre niveauer i tekstgenreforskningen. In LSP News 10. 3142.

Frandsen, Finn (1995b): De journalistiske genrer som tekstlingvistisk problem. In Kunøe, M./Vive Larsen, E. (red.): 5. Mфde om Udforskningen af Dansk Sprog. Aarhus Universitet. 59-67.

Frandsen, Finn (1996): Tekstlingvistik. Portræt af en disciplin og en avisartikel. In Jørgensen, K. Gall/Geist, U. (red.): Det nye korstog. Sproganalytiske vinkler på en sagprosatekst. Frederiksberg: Roskilde Universitetsforlag. 127-148.

Frandsen, Finn/Pilegaard, Morten (1997): Text type. In Verschuren, J./Östman, J.-O./Blommaert, J./Bulcaen, C. (eds.): Handbook of Pragmatics. Amsterdam: Johan Benjamins.

Hastrup, Thure (1976): Grask og romersk talekunst. København: Berlingske Forlag.

Hatim, Basil/Mason, Ian. (1990): Discourse and the Translator. London: Longman.

Heinemann, Wolfgang/Viehweger, Dieter (1991): Textlinguistik. Eine Einführung. Tübingen: Niemeyer. 
Jacobson, Roman (1960): Closing Statements: Linguistics and Poetics. In Seboek, T.A. (ed.): Style in Language. Cambridge, Mass.: MIT Press. 350377.

Jacques, Francis (1987): Le mouvement du texte. In Greisch, J. (éd.): Le texte comme objet philosophique. Paris: Beauchesne. 15-85.

Longacre, Robert E. (1982): Discourse Typology in Relation to Language Typology. In Allén, S. (ed.): Text Processing. Text Analysis and Generation. Text Typology and Attribution. Proceedings of Nobel Symposium 51. Stockholm: Almqvist \& Wiksell International. 457-497.

Longacre, Robert E. (1983): The Grammar of Discourse. New York: Plenum Press.

Maingueneau, Dominique (1986): Eléments de linguistique pour le texte littéraire. Paris: Bordas.

Morris, Charles (1946): Signs, Language and Behavior.

Nølke, Henning (1989): Polyfoni. En sprogteoretisk indføring. Ark 48. Sproginstitutternes Arbejdspapir. Handelshøjskolen i København.

Peytard, Jean/Moirand, Sophie (1992): Discours et enseignement du français. Paris: Hachette.

Pratiques 56 (1987): temanummer om "Les types de textes".

Rehfeld, Vibeke/Therkelsen, Rita (1996): Genren - spillereglerne forud for teksten. In Jørgensen, K. Gall/Geist, U. (red.): Det nye korstog. Sproganalytiske vinkler på en sagprosatekst. Frederiksberg: Roskilde Universitetsforlag. 16-32.

Ricoeur, Paul (1983-85): Temps et récit I-III. Paris: Le Seuil.

Roulet, Eddy (1991): Une approche discursive de l'hétérogénéité discursive. In Etudes de linguistique appliquée 83. 117-130.

Schneuwly, Bernard (1987): Quelle typologie de textes pour l'enseignement? Une typologie des typologies. In Chiss, J.L./Laurent, J.P./Meyer, J.C./ Romian, H./Schneuwly, B. (éds.): Apprendre/enseigner à produire des textes écrits. Bruxelles: De Boeck.

Schneuwly, Bernard (1991): Diversification et progression en DFLM : l'apport des typologies. In Etudes de linguistique appliquée 83. 131-141.

Weinrich, Harald (1973): Le temps. Paris: Le Seuil.

Werlich, Egon (1975): Typologie der Texte. Heidelberg: Quelle \& Meyer.

Werlich, Egon (1976): A Text Grammar of English. Heidelberg: Quelle \& Meyer.

Virtanen, Tuija (1992): Issues of Text Typology: Narrative - a 'Basic' Type of Text. In Text 12 (2). 293-310. 